\title{
GRASI DALAM KONSEP TUJUAN PEMIDANAAN
}

Oleh:

Titik Suharti

\begin{abstract}
Grasi represent one of form of[is reason of crime liquidator and represent the medium to get the pardon in the form of change, extenuation, reduction, or abolition of crime execution which have been knocked down to be punished [by] pursuant to justice decision obtained the legal force remain to, as arranged in Law No 22 Thn 2002 about Grasi.
\end{abstract}

Keyword : Grasi, Legal Force Remain To, Criminal Law

\section{PENDAHULUAN}

Hukum pidana adalah bagian dari keseluruhan hukum yang berlaku di suatu Negara, yang mengadakan dasar-dasar dan aturan-aturan untuk:

1. menentukan perbuatan-perbuatan mana yang tidak boleh dilakukan, yang dilarang, dengan disertai ancaman atau sanksi yang berupa pidana tertentu bagi barangsiapa melanggar larangan tersebut;

2. menentukan kapan dan dalam halhal apa kepada mereka yang telah melanggar larangan-larangan itu dapat dikenakan atau dijatuhi pidana sebagaimana yang telah diancamkan;

3. menentukan dengan cara bagaimana pengenaan pidana itu dapat dilaksanakan apabila ada orang yang disangka telah melanggar larangan tersebut. (Moeljatno, 2000:1)

Ciri utama dari hukum pidana adalah adanya sanksi pidana atau adanya pemidanaan. Adapun unsur-unsur atau cirri-ciri yang terkandung dalam sanksi pidana adalah:

1. pidana pada hakekatnya merupakan suatu pengenaan penderitaan atau nestapa atau akibat-akibat lain yang tidak menyenangkan;

2. pidana diberikan dengan sengaja oleh orang atau badan yang mempunyai kekuasaan;

3. pidana dikenakan kepada seseorang yang telah melakukan tindak pidana menurut undangundang. (Muladi dan Barda Nawawi A, 1998:4) 
Kitab Undang-undang Hukum Pidana sebagai induk dari peraturan perundang-undangan pidana di Indonesia mengatur juga tentang pidana dan pemidanaan. Pasal 10 Kitab Undangundang Hukum Pidana menyebutkan ada 2 (dua) macam pidana, yaitu pidana pokok dan pidana tambahan. Pidana pokok terdiri dari pidana mati, pidana penjara, pidana kurungan dan pidana denda. Pidana tambahan terdiri dari pencabutan hak-hak tertentu, perampasan barangbarang tertentu dan pengumuman putusan hakim.

Bentuk pidana pokok yang seringkali memunculkan permasalahan kompleks adalah pidana mati dan pidana penjara. Menurut ketentuan pasal 11 Kitab Undang-undang Hukum Pidana, pidana mati dilakukan oleh seorang algojo terhadap terpidana dengan cara digantung, yaitu dengan mengikatkan sebuah jerat pada leher terpidana yang terikat pada tiang gantungan dan kemudian menjatuhkanpapan tempat terpidana berpijak. Pelaksanaan pidana mati tersebut telah dirubah dengan cara ditembak sampai mati melalui Penetapan Presiden tanggal 27 April 1964 No 2 Thn 1964 dan diundangkan dalam Lembaran
Negara No 38 Thn 1964,yang kemudian menjadi Undang-undang No 2 Pnps Thn 1964. Dalam peraturan perundangundangan pidana di Indonesia, ancaman pidana mati selalu dialternatifkan dengan ancaman pidana penjara seumur hidup maupun pidana penjara selama waktu tertentu.

Menurut P.A.F. Lamintang sebagaimana dikutib oleh Dwidja Priyatno mengemukakan bahwa pidana penjara adalah suatu pidana berupa pembatasan kebebasan bergerak dari seorang terpidana, yang dilakukan dengan menutup orang tersebut di dalam sebuah lembaga pemasyarakatan, dengan mewajibkan orang itu untuk mentaati semua peraturan tata tertib yang berlaku di dalam lembaga pemasyarakatan, yang dikaitkan dengan sesuatu tindakan tata tertib bagi mereka yang telah melanggar peraturan tersebut. (Dwidja Priyatno, 2004:71)

$$
\text { Grasi merupakan salah satu }
$$
bentuk alasan penghapus pidana, yang pengaturannya ada di luar Kitab Undangundang Hukum Pidana, tepatnya diatur dalam Undang-undang No 22 Thn 2002 tentang Grasi. Grasi merupakan sarana untuk mendapatkan pengampunan 
berupa perubahan, peringanan, pengurangan, atau penghapusan pelaksanaan pidana yang telah dijatuhkan kepada terpidana berdasarkan putusan pengadilan yang telah memperoleh kekuatan hukum tetap.

Undang-undang No 22 Thn 2002 memberikan definisi grasi adalah pengampunan berupa perubahan, peringanan, pengurangan, atau penghapusan pelaksanaan pidana kepada terpidana yang diberikan oleh Presiden. Adapun definisi terpidana adalah seseorang yang dipidana berdasarkan putusan pengadilan yang telah memperoleh kekuatan hukum tetap.

\section{RUMUSAN MASALAH}

Berdasarkan uraian tersebut di atas, dapat dirumuskan permasalahan sebagai berikut: Bagaimana pengaturan tentang grasi dalam kaca pandang konsep tujuan pemidanaan?

\section{PEMBAHASAN}

\section{PENGATURAN TENTANG GRASI}

Undang-undang Dasar Negara Republik Indonesia Tahun 1945 pasal 14 ayat (1) menyatakan bahwa Presiden memberikan grasi dan rehabilitasi dengan memperhatikan pertimbangan Mahkamah Agung. Undang-undang No 3 Thn 1950 tentang Permohonan Grasi dibuat pada masa Republik Indonesia Serikat, sehingga tidak sesuai lagi dengan sistem ketatanegaraan Indonesia yang berlaku saat ini. Berdasar pada hal tersebut, maka Undang-undang No 3 Thn 1950 tentang Permohonan Grasi diganti dengan Undang-undang No 22 Thn 2002 tentang Grasi.

Grasi adalah pengampunan berupa perubahan, peringanan, pengurangan, atau penghapusan pelaksanaan pidana kepada terpidana yang diberikan oleh Presiden. Terpidana dapat mengajukan permohonan grasi terhadap putusan pengadilan yang telah memperoleh kekuatan hukum tetap kepada Presiden. Menurut penjelasan pasal 2 ayat (1), yang dimaksud dengan putusan pengadilan yang telah memperoleh kekuatan hukum tetap adalah:

a. putusan pengadilan tingkat pertama yang tidak diajukan banding atau kasasi dam waktu yang ditentukan oleh Undang-undang tentang Hukum Acara Pidana;

b. putusan pengadilan tingkat banding 
yang tidak diajukan kasasi dalam waktu yang ditentukan oleh Undang-undang tentang Hukum Acara Pidana; atau

c. putusan kasasi.

Adapun putusan pemidanaan yang dapat dimohonkan grasi kepada Presiden adalah putusan penjatuhan pidana mati, pidana penjara seumur hidup atau pidana penjara paling rendah 2 (dua) tahun. Undang-undang No 22 Thn 2002 tentang Grasi tidak memberikan batasan waktu untuk pengajuan permohonan grasi kepada Presiden oleh terpidana.

Sebagaimana diatur dalam pasal 2 ayat (3) Undang-undang No 22 Thn 2002 tentang Grasi, permohonan grasi hanya dapat diajukan 1 (satu) kali, kecuali dalam hal:

a. terpidana yang pernah ditolak permohonan grasinya dan telah lewat waktu 2 (dua) tahun sejak tanggal penolakan grasi tersebut;

b. terpidana yang pernah diberi grasi dari pidana mati menjadi pidana seumur hidup dan telah lewat waktu 2 (dua) tahun sejak tanggal keputusan pemberian grasi diterima.
Pasal 3 menyebutkan bahwa permohonan grasi tidak menunda pelaksanaan putusan pemidanaan bagi terpidana, kecuali dalam hal putusan pidana mati.

Menurut Undang-undang No 22 Thn 2002 tentang Grasi, pemberian grasi oleh presiden dapat berupa:

a. peringanan atau perubahan jenis pidana;

b. pengurangan jumlah pidana; atau

c. penghapusan pelaksanaan pidana.

\section{TUJUAN PEMIDANAAN}

Secara tradisional, teori-teori pemidanaan sebagai dasar pembenar dan tujuan pemidanaan dapat dibagi ke dalam 2 (dua) kelompok teori, yaitu:

a. teori absolute atau teori pembalasan (retributive/vergelding theorieen)

b. teori relative atau teori tujuan (utilitarian/doeltheorieen)

Berdasarkan teori absolut, pidana dijatuhkan semata-mata karena orang telah melakukan suatu kejahatan atau perbuatan pidana. Setiap kejahatan harus diikuti dengan pidana. Seseorang dikenakan sanksi pidana karena ia telah melakukan perbuatan pidana. 


\section{Menurut pendapat Nigel}

Walker sebagaimana dikutib oleh Dwidja Priyatno ada 2 (dua) golongan penganut teori absolute, yaitu:

1. penganut teori absolut murni (the pure retributivist), yang berpendapat bahwa pidana harus cocok dengan kesalahan pelaku;

2. penganut teori absolut tidak murni, dapat pula dibagi ke dalam:

a. penganut teori absolut yang terbatas (the limiting retributivist) berpendapat bahwa pidana tidak harus sepadan dengan kesalahan, hanya saja tidak boleh melebihi batas yang cocok dengan kesalahan terdakwa;

b. penganut teori absolut yang distributif (retribution in distribution), dan biasa disebut dengan teori distributive yang berpendapat bahwa pidana tidak dikenakan pada orang yang tidak bersalah tetapi pidana juga tidak harus sepadan dan dibatasi oleh kesalahan; prnsip "tiada pidana tanpa kesalahan" tetap perhatikan, tetapi dimungkinkan adanya pengecualian dengan diterapkannya teori strict liability. (Dwidja Priyatno, 2004:24-25)

Berdasarkan teori relatif, penjatuhan pidana bukanlah untuk mempunyai nilai, tetapi hanya sebagai sarana untuk melindungi kepentingan masyarakat. Menurut J. Andenaes, teori ini dapat disebut dengan teori perlindungan masyarakat (the theory of social defence). Sedangkan menurut Nigel Walker, teori ini lebih tepat disebut teori atau aliran reduktif (the reductive point of view) karena dasar pembenaran pidana adalah untuk mengurangi frekuensi kejahatan, sehingga para penganutnya dapat disebut golongan Reducer, yaitu penganut teori reduktif.

Muladi dan Barda Nawawi Arief dalam bukunya tentang Teori-teori Kebijakan Pidana menjelaskan bahwa pidana bukanlah sekedar untuk melakukan pembalasan atau pengimbalan kepada orang yang telah melakukan suatu perbuatan pidana, tetapi mempunai tujuan-tujuan tertentu yang bermanfaat, 
sehingga teori ini sering disebut teori tujuan (utilitarian theory). Jadi dasar pembenaran pidana menurut teori relatif adalah terletak pada tujuannya. Pidana dijatuhkan bukan Quia peccatum est (karena orang melakukan kejahatan) melainkan ne peccatum (supaya orang jangan melakukan kejahatan). (Muladi dan Barda Nawawi Arief, 1984:13-16) Karl O Cristiansen, sebagaimana dikutib oleh Dwidja Priyatno, Memberikan ciri pokok atau karakteristik antara teori absolut dan teori relatif sebagai berikut:

a. pada teori absolut:

tujuan pidana adalah sematamata untuk pembalasan;

i. pembalasan adalah tujuan utama dan di dalamnya tidak mengadung saranasarana untuk tujuan lain, misalnya untuk kesejahteraan masyarakat;

ii. kesalahan merupakan satu-satunya syarat untuk adanya pidana;

iii. pidana harus disesuaikan dengan kesalahan si pelanggar;

iv. pidana melihat kebelakang, karena merupakan pencelaan yang murni dan tujuannya tidak untuk memperbaiki, mendidik atau memasyarakatkan kembali si pelanggar;

b. pada teori relatif:

i. tujuan pidana adalah pencegahan (prevention);

ii. pencegahan bukan tujuan akhir tetapi hanya sebagai sarana untuk mencapai tujuan yang lebih tinggi, yaitu kesejahteraan masyarakat;

iii. hanya pelanggaranpelanggaran hukum yang dapat dipersalahkan kepada si pelaku, misalnya karena sengaja atau culpa, yang memenuhi syarat untuk adanya pidana;

iv. pidana harus ditetapkan berdasar tujuannya sebagai alat untuk pencegahan kejahatan;

v. pidana melihat ke muka, yaitu bersifat prospektif, pidana dapat mengandung unsur pencelaan, tetapi 
baik unsur pencelaan maupun unsur pembalasan tidak dapat diterima apabila tidak membantu pencegahan kejahatan untuk kepentingan kesejahteraan masyarakat.

Selain kedua teori pemidanaan tersebut di atas, terdapat teori ketiga yang disebut Teori Gabungan (verenigings theorieen). Teori gabungan pertama kali ditulis oleh Pellegrino Rossi. Menurut Pellegrino Rossi, pembalasan tetap sebagai asas dari penjatuhan pidana, namun dia berpendirian bahwa pidana mempunyai berbagai pengaruh antara lain perbaikan sesuatu yang rusak dalam masyarakat dan prevebsi general. (Muladi dan Barda Nawawi Arief, 1984:19)

Dalam Rancangan Kitab Undang-undang Hukum Pidana Thn 2004 telah disepakati bahwa tujuan pemidanaan adalah:

a. mencegah dilakukannya perbuatan pidana dengan menegakkan norma hukum demi pengayoman masyarakat;

b. memasyarakatkan terpidana dengan mengadakan pembinaan sehingga menjadikan orang yang baik dan berguna;

c. menyelesaikan konflik yang ditimbulkan oleh perbuatan pidana, memulihkan keseimbangan dan mendatangkan rasa damai dalam masyarakat;

d. membebaskan rasa bersalah pada diri terpidana.

Ditegaskan pula dalam Rancangan Kitab Undang-undang Hukum Pidana bahwa pemidanaan tidak dimaksudkan untuk menderitakan dan tidak diperkenankan merendahkan martabat manusia.

Tujuan pemidanaan akan dikonkritkan dalam bentuk pedoman pemidanaan (Straftoemeting leiddraad). Pedoman pemidanaan akan dipengaruhi oleh aliran-aliran dalam hukum pidana. Dalam hukum pidana ada 3 (tiga) aliran, yaitu:
a. aliran klasik;
b. aliran modern;
c. aliran neoklasik.

Aliran klasik menitikberatkan pada perbuatan dan tidak pada orang yang melakukan tindak pidana. Hukum pidana yang demikian adalah hukum pidana perbuatan (daadstrafrecht). Aliran klasik berpijak pada 3 (tiga) hal, yaitu: 
a. asas legalitas, yang menyatakan bahwa tiada pidana tanpa undang-undang, tiada tindak pidana tanpa ndang-undang dan tiada penuntutan tanpa undangundang;

b. asas kesalahan, yang berisi bahwa orang hanya dapat dipidana untuk tindak pidana yang dilakukannya dengan sengaja atau karena kealpaan;

c. asas pengimbalan (pembalasan) yang sekuler, yang berisi bahwa pidana secara konkrit tidak dikenakan dengan maksud untuk mencapai sesuatu hasil yang bermanfaat, melainkan setimpal dengan berat ringannya perbuatan yang dilakukan. (Muladi dan Barda Nawawi Arief, 1984:26-27)

Aliran klasik memiliki karakteristik sebagai berikut:

a. definisi hukum dari kejahatan (legal definition of crime);

b. pidana harus sesuai dengan kejahatan (let the punishmentfit the crime);

c. doktrin kebebasan kehendak (doctrine of free will);

d. pidana mati untuk beberapa tindak pidana (death penalty for some offenses);

e. tidak ada riset empiris (anecdotal method; no empirical research);

f. pidana yang ditentukan secara pasti (definite sentence). (Muladi dan Barda Nawawi Arief, 1984:39)

Menurut aliran modern, perbuatan seseorang tidak dapat dilihat secara abstrak dari sudut yuridis yang terplepas dari orang yang melakukannya, tetapi harus dilihat secara konkrit bahwa dalam kenyataannya perbuatan seseorang dipengaruhi oleh watak pribadinya, faktor-faktor biologis atau faktor lingkungan kemasyarakatan.

Ciri-ciri aliran modern adalah sebagai berikut:

i. menolak definisi hukum dari kejahatan (rejected legal definition of crime);

ii. pidana harus sesuai dengan pelaku tindak pidana (let the punishment fit the criminal);

iii. doktrin determinisme (doctrine of determinisme);

iv. penghapusan pidana mati (abolition of the death penalty);

v. riset empiris (empirical research; use of the inductive method); 
vi. pidana yang tidak ditentukan secara pasti (indeterminate sentence). (Muladi, 1985:43)

Menurut aliran neoklasik, pidana yang dihasilkan oleh aliran klasik terlalu berat dan merusak semangat kemanusiaan. Aliran neoklasik mulai mempertimbangkan kebutuhan adanya pembinaan individual dari pelaku perbuatan pidana. (Dwidja Priyatno, 2004:34-35) Adapun ciri-ciri dari aliran neoklasik adalah:

a. modifikasi dari doktrin kebebasan berkehendak yang dapat dipengaruhi oleh patologi;

b. diterima berlakunya keadaankeadaan yang meringankan;

c. modifikasi dari doktrin pertanggungjawaban untuk mengadakan peringanan pemidanaan, dengan kemungkinan adanya pertanggungjawaban sebagian di dalam kasuskasus tertentu seperti penyakit jiwa, usia dan keadaankeadaan lain yang dapat mempengaruhi pengetahuan dan kehendak seseorang pada saat terjadinya kejahatan; d. masuknya kesaksian ahli di dalam acara peradilan guna menentukan derajat pertanggungjawaban. (Muladi, 1985:43)

\section{GRASI DALAM KONSEP TUJUAN PEMIDANAAN}

Berdasarkan ketiga aliran tujuan pemidanaan, yaitu aliran klasik, aliran modern, dan aliran neoklasik, maka pembahasan tentang grasi dalam konsep tujuan pemidanaan lebih menekankan pada filosofi pengaturan grasi dalam Undang-undang No 22 Thn 2002 tentang Grasi dikaitkan dengan konsep tujuan pemidanaan.

Grasi merupakan salah satu bentuk alasan penghapus pidana dan merupakan sarana untuk mendapatkan pengampunan berupa perubahan, peringanan, pengurangan, atau penghapusan pelaksanaan pidana yang telah dijatuhkan kepada terpidana berdasarkan putusan pengadilan yang telah memperoleh kekuatan hukum tetap. Grasi diberikan oleh presiden kepada terpidana. Putusan pemidanaan yang dapat dimohonkan grasi kepada Presiden adalah putusan penjatuhan 
pidana mati, pidana penjara seumur hidup atau pidana penjara paling rendah 2 (dua) tahun. Pengajuan permohonan grasi tidak dibatasi waktu dan hanya dapat diajukan 1 (satu) kali, kecuali dalam hal-hal tertentu, misalnya terpidana yang pernah ditolak permohonan grasinya dan telah lewat waktu 2 (dua) tahun sejak tanggal penolakan grasi tersebut; Grasi tidak menunda pelaksanaan putusan pemidanaan bagi terpidana, kecuali dalam hal putusan pidana mati.

Pengaturan tentang grasi sebagaimana diatur dalam Undangundang No 22 Thn 2002, merupakan wujud bahwa pemidanaan di Indonesia masih memperhatikan unsur balas dendam sebagaimana dianut dalam teori absolut atau teori pembalasan (retributive / vergelding theorieen). Berdasarkan teori absolut, pidana dijatuhkan semata-mata karena orang telah melakukan suatu kejahatan atau perbuatan pidana. Setiap kejahatan harus diikuti dengan pidana. Seseorang dikenakan sanksi pidana karena ia telah melakukan perbuatan pidana, sehingga pengajuan grasi didasarkan pada adanya sanksi pidana yang dijatuhkan terhadap pelaku perbuatan pidana. Pelaku mengajukan grasi untuk mendapatkan pengampunan berupa perubahan, peringanan, pengurangan, atau penghapusan pelaksanaan pidana. Apapun keputusan tentang grasi, hal itu didasarkan pada pertimbangan yang ada pada diri pelaku maupun kejahatan yang telah dilakukan. Dengan demikian bisa disimpulkan bahwa keputusan tentang grasi merupakan cerminan dari dipertimbangkannya teori absolut.

Namun, pengaturan tentang grasi juga memperhatikan kepentingan masyarakat yang berarti bahwa penjatuhan pidana merupakan sarana untuk melindungi kepentingan masyarakat. Berdasarkan teori relatif atau teori tujuan (utilitarian / doeltheorieen), penjatuhan pidana bukanlah untuk mempunyai nilai, tetapi hanya sebagai sarana untuk melindungi kepentingan masyarakat. Sebagaimana ditegaskan dalam Rancangan Kitab Undang-undang Hukum Pidana bahwa pemidanaan tidak dimaksudkan untuk menderitakan dan tidak diperkenankan merendahkan martabat manusia.

Dalam hukum pidana ada 3 (tiga) aliran, yaitu aliran klasik, aliran modern dan aliran neoklasik. Pengaturan 
tentang grasi sebagaimana diatur dalam Undang-undang No 22 Thn 2002 sedikit banyak telah mempertimbangkan kebutuhan adanya pembinaan individual dari pelaku perbuatan pidana. Salah satu karakteristik dari teori neoklasik adalah modifikasi dari doktrin pertanggung jawaban untuk mengadakan peringanan pemidanaan. Peringanan pemidanaan bisa dilakukan melalui upaya pengajuan permohonan grasi.

\section{PENUTUP}

Grasi merupakan salah satu bentuk alasan penghapus pidana dan merupakan sarana untuk mendapatkan pengampunan berupa perubahan, peringanan, pengurangan, atau penghapusan pelaksanaan pidana yang telah dijatuhkan kepada terpidana berdasarkan putusan pengadilan yang telah memperoleh kekuatan hukum tetap, sebagaimana diatur dalam Undang-undang No 22 Thn 2002 tentang Grasi.

Pengaturan tentang grasi sebagaimana diatur dalam Undang-undang No 22 Thn 2002, merupakan wujud bahwa pemidanaan di Indonesia masih memperhatikan unsur balas dendam sebagaimana dianut dalam teori absolut atau teori pembalasan (retributive/vergelding theorieen).

Namun, pengaturan tentang grasi juga memperhatikan kepentingan masyarakat yang berarti bahwa penjatuhan pidana merupakan sarana untuk melindungi kepentingan masyarakat.

Pengaturan tentang grasi sedikit banyak telah mempertimbangkan kebutuhan adanya pembinaan individual dari pelaku perbuatan pidana. Salah satu karakteristik dari teori neoklasik adalah modifikasi dari doktrin pertanggung jawaban untuk mengadakan peringanan pemidanaan. Peringanan pemidanaan bisa dilakukan melalui upaya pengajuan permohonan grasi.

\section{DAFTAR PUSTAKA}

Dwidja Priyatno, Kebijakan Legistatif Tentang Sistem Pertanggung Jawab Pidana Korporasi Di Indonesia, Cv Utomo Bandung, 2004

Barda Nawawi Arief, Kapita Selekta Hukum Pidana, PT. Citra Bakti, Bandung, 2003

Moeljatno, Asas - Asas Hukum Pidana, Rineka Cipta, Jakarta, 2000

Wirjono Prodjodikoro, Asas - Asas Hukum Pidana Di Indonesia, Refika Aditama, Bandung , 2003 